\title{
Effect of Digestate from Rubber Processing Effluent on Soil Properties
}

\author{
M. Maliki ${ }^{1, *}$, Ifijen I. H $^{2}$, M. E. Khan ${ }^{3}$ \\ ${ }^{1}$ Edo University Iyamho. ${ }^{2}$ Rubber Research Institute Iyanomo. ${ }^{3}$ University of Agriculture, \\ Makurdi \\ *Corresponding author. (6) +2348125817458 @ muniratu.maliki@edouniversity.edu.ng
}

\begin{abstract}
Anaerobic digestion of rubber processing effluent (RPE) was conducted at 1:1 Effluent to Inoculums ratio to obtain biogas at a 40-day retention time. The physicochemical properties of the RPE were determined before and after anaerobic digestion. Digestate obtained thereof was used as soil amendment to investigate its bio-fertility potential. To study the effects, three kilograms $(3 \mathrm{Kg})$ of soil samples were separately treated with $0,200,400,600$ of the digested RPE. The effluent applied were thoroughly mixed with the soil, watered regularly and left for eight weeks for adequate mineralisation and equilibration. The soil physicochemical properties were determined before and after the amendment. The results from the amended soils showed that application of the digestate enhanced soil quality (as soil organic carbon, N, P, K, Ca, Na and \% base saturation were significantly higher than in the control). However, the soil $\mathrm{pH}$ remained in the acidic region and the soil exchangeable acidity reduced.
\end{abstract}

Keywords: Digestate, soil properties, biogas, RPE.

\section{Introduction}

Rubber tree (Hevea brasiliensis), belonging to the family Euphorbiaceae is one of the major tree crops in Nigeria. It is cultivated on plantations in the tropics and subtropics, especially in Southeast Asia and western Africa. It is a soft wood, with high branching limbs; and a large area of bark. The milky liquid (latex) that oozes from any wound to the tree bark contains about 30 percent rubber, which can be coagulated and processed into solid products, such as tires. Latex can also be concentrated for producing dipped goods, such as surgical gloves (Pal, 1991). Product preparations from latex generate different type of wastes.

Amongst the different waste generated by rubber processing, effluent from rubber processing (RPE) is the most polluting and difficult waste to manage. This is because the process consumes large amount of water and as a result generates large quantities of unavoidable effluent waste (RPE) (Leong et al., 2003; Babel and Rungruang, 2008). Averagely, about 20,500 litres of rubber processing effluent is generated per ton of rubber processed (Mohammadi et al., 2010). No matter the efficiency of the extraction process, the effluent 
constituent includes wash water, small amounts of uncoagulated latex, serum with little quantities of protein, carbohydrates, lipids, carotenoids, and salts along with any chemical that might have been added to make the process practically better (Asia and Akporhonor 2007; Chua and Garces, 1992; Hutagalung; 2003; Tekasakul and Tekasakul, 2006). The effluent has a very offensive odour, characterized with high organic content, high COD and as such harmful to the environment when discharged indiscriminately. Conventionally the effluent is released straight or indirectly into water bodies as a cheap disposal method, leading to reduction in the dissolved oxygen in the waters, deteriorating them into an unsightly, foul- smelling and disease causing conditions. By this action, aquatic lives and lives of nearby inhabitants are endangered (Abdurahman et al., 2011; Mohammadi et al., 2010). In Nigeria where environmental pollution laws are not strictly adhered to, the impact of such indiscriminate disposal can be more devastating. So far, report from WHO has estimated 335,200 deaths, (a 16.70\% of death cases occurring annually in Nigeria) as a result of poor sanitation, water and hygiene related infection (Ojuri and Ola 2010; Ojuri et al., 2014). Therefore, proper management of the effluent is a matter to be considered seriously for environmental concern and sustainable farming. A suitable option in tackling this problem is the use of anaerobic digestion to treat the effluent (Sunarso et al., 2012). The process offers several advantages because while producing energy from waste; it is also simultaneously preventing adverse environmental impacts. In order to maximise the benefit of this waste, it is important to evaluate its bio- fertility potentials.

Bio-fertility potentials of organic fertilizers have been fully established. And nowadays, there is a drift from the use of inorganic fertilizers to bio-fertilizers due to their several benefits. Results from soil amendments with manure, composts, and agricultural waste are of the same conclusion that they are environment friendly with improved and balanced nutrients supplies which include micronutrients. They have increased soil microbial activity which enhances soil structure, root development, increased soil water availability and decomposition of harmful elements (Han et al., 2016). However, recent articles report that the effects of anaerobic slurries upon the receiving soil may range from soil amendment to that of soil pollution. Therefore, there is a conflict between the benefits and risk of the agronomic use of digestates. And as such the competence of anaerobic slurries as bio-fertilizers has not been fully established. Thus, in continuation for the search for a more environment friendly, profitable and cost effective waste management technique, this study examines the effect of digestate obtained rubber processing effluent on soil properties.

\section{Experiment}

\section{Collection, Anaerobic Digestion and Analysis of the Effluent}

Rubber processing effluent (RPE) was obtained from the Okomu Oil Mill. The wastewater was collected from the discharge unit of the sewage systems and cow dung inoculum was collected from a slaughter house in Oluku. All samples were collected in Benin City, Edo state in triplicates in pre-sterilized bottles and stored in a refrigerator at $4^{\circ} \mathrm{C}$ before use. The rubber processing effluent (RPE) was treated separately with cow dung inoculum at 1:1 effluent to inoculum (E: I) ratio in a closed anaerobic digester at $80 \%$ organic loading rate (OLR), using the mesospheric technique (Vavilin et al., 2008). The physiochemical properties the effluent were analysed before and after anaerobic digestion using standard methods (Ademoroti, 1996; APHA, 1999; Rebecca, 2004). 


\section{Sampling, Treatment and characterization of soil samples}

Composite soil samples were collected using the auger at a depth of $0-30 \mathrm{~cm}$ from an uncultivated land behind the Faculty of Agriculture University of Benin, Benin City, Nigeria. The samples were air-dried, sieved through $2 \mathrm{~mm}$ stainless steel sieve and thoroughly mixed to ensure uniformity and then stored in polythene bags at room temperature.

Thereafter, three kilograms $(3 \mathrm{~kg})$ each of soil samples were separately treated with $0 \mathrm{ml}$, $200 \mathrm{ml}, 400 \mathrm{ml}$, and $600 \mathrm{ml}$ of the digestate in triplicate. The effluents applied were thoroughly mixed with the soil and the pots were arranged in a completely randomised design. The soils were watered regularly and left for eight weeks to allow for adequate mineralization and equilibration. Physicochemical properties of the soils were analysed before and after soil treatment using standard methods. The soil $\mathrm{pH}$ was determined in a 1:10 (w/v) ratio of soil to distilled water using a $\mathrm{pH}$ meter. The soil textural analysis was determined by using the hydrometer method by Day using sodium hexametaphosphate as the dispersant (Osaigbovo and Orhue 2011). Organic carbon was determined by the chromic acid wet oxidation method (Osaigbovo and Orhue 2011). Total nitrogen and available phosphorus were determined using the methods (Udo et al., 2009). The metal content (Mg, Ca, Al, $\mathrm{Cu}$ and $\mathrm{Mn}$ ) was determined using the atomic absorption spectrophotometer (Bulk Scientific VGP 210 model) while K and $\mathrm{Na}$ were determined by flame absorption spectrophotometer (Bulk Scientific model 200A). The summation of the exchangeable cation $\left(\mathrm{Na}^{+}, \mathrm{K}^{+}, \mathrm{Mg}^{2+}, \mathrm{Ca}^{2+}\right)$ and exchangeable acidity $\left(\mathrm{H}^{+}\right.$and $\mathrm{Al}^{3+}$ ) was reported as cation exchange capacity (CEC). The $\%$ base saturation was determined by the summation of the cation $\left(\mathrm{K}^{+}, \mathrm{Mg}^{2+}, \mathrm{Ca}^{2+}\right)$ divided by the CEC.

\section{Analysis}

One-way analysis of variance (ANOVA) was carried out to assess the significant differences in the data obtained. The mean of the data was compared using SPSS (Statistical package for Social Scientist).

\section{Results and Discussion}

Table 1 shows the physicochemical properties of the effluent before and after anaerobic. From the results, it is observed that the rubber processing effluent had $\mathrm{pH}$ value of 6.60. Their $\mathrm{pH}$ values suggest that the effluent are slightly acidic and within the regulatory discharge limits for effluent (Ma, 2000; Ahmad et al., 2003). Acidic $\mathrm{pH}$ values are consistent with some previous studies on RPE, Pal, (1991) reported a $\mathrm{pH}$ value of 5.70 and $\mathrm{pH}$ value of 5.0 was reported by Orhue and Osaigbovo (2013). $\mathrm{pH}$ value ranging between 3.70 -5.50 has also been reported (Rungruang and Babel, 2008; Chua and Garces, 1992). However, Asia and Akporhonor (2007) had a contrary value of 8.1. Rubber processing effluent is characterized by a highly fluctuating $\mathrm{pH}$ (Mohammadi et al., 2010). The suspended solid $(568 \mathrm{mg} / \mathrm{l})$ was not within the regulatory discharge limits for wastewater (Ma, 2000; Ahmed et al., 2003). Total Solids (1,450mg/l) and COD $(1,801.74 \mathrm{mg} / \mathrm{l})$ were very high, indicating that the effluent has high pollution potentials. The COD values for RPE obtained in this study was higher than values (3142 mg/l) obtained by Asia and Akpohonor (2007) in a related study but consistent with Orhue and Osaigbovo (2013). 
Table 1. Physicochemical Properties of the RPE before and after Anaerobic Digestion

\begin{tabular}{llll}
\hline Properties & $\begin{array}{l}\text { Okomu RPE } \\
\text { mean } \pm \text { SD }\end{array}$ & $\begin{array}{l}\text { Okomu Digestate } \\
\text { mean } \pm \text { SD }\end{array}$ & $\begin{array}{l}\text { Regulatory Discharge } \\
\text { Limit(Ma, 2000; } \\
\text { Ahmed } \text { et al., 2003) }\end{array}$ \\
\hline $\mathrm{pH}$ & $6.60 \pm 0.01$ & $7.60 \pm 0.01$ & $5.0-9.0$ \\
Organic Carbon $\%$ & $0.31 \pm 0.01$ & $0.78 \pm 0.01$ & - \\
$\mathrm{COD}$ & $1,801.74 \pm 0.02$ & $672.65 \pm 0.05$ & - \\
Total Solids & $1,450.00 \pm 5.00$ & $1,650.00 \pm 2.00$ & - \\
Volatile Solids & $143.00 \pm 1.00$ & $175.00 \pm 2.00$ & - \\
Suspended Solid & $568.00 \pm 1.00$ & $1,540.00 \pm 2.00$ & 400 \\
Oil\& Grease & $8.90 \pm 0.01$ & $4.10 \pm 0.05$ & 50 \\
Calcium & $8.86 \pm 0.02$ & $155.00 \pm 1.00$ & - \\
Magnesium & $1.94 \pm 0.01$ & $48.60 \pm 0.10$ & - \\
Phosphate & $0.85 \pm 0.01$ & $21.00 \pm 0.02$ & \\
Potassium & $112.25 \pm 0.02$ & $168.38 \pm 0.02$ & \\
Sodium & $1.54 \pm 0.01$ & $23.45 \pm 0.01$ & \\
Nitrate & $0.05 \pm 0.00$ & $1.07 \pm 0.15$ & \\
Sulphate & $8.00 \pm 0.13$ & $10.00 \pm 0.04$ & \\
Copper & $20.11 \pm 0.01$ & $12.60 \pm 0.05$ & \\
Manganese & $20.81 \pm 0.02$ & $14.28 \pm 0.01$ & \\
\hline
\end{tabular}

All values, except conductivity, $\mathrm{pH}$ and temperature are expressed in $\mathrm{mg} / \mathrm{l}$.

The results also reveal that the COD of the effluent was considerably reduced by the treatment, leading to a COD reduction of about $60 \%$. Oil and grease was also reduced with anaerobic treatment. However, other water properties such as total solids, sulphate, nitrate etc., were not considerably affected by the treatments. Apparently, the complex materials that could not be broken down by the anaerobic microorganism along with the remains of the dead microorganisms within the digester could have contributed to the observation. This also explains why the digestate was rich in nutrient. COD reduction has been associated with anaerobic treatments of various effluents. Membrane Anaerobic System (MAS) was found to be a successful biological treatment system that achieved a very high COD removal efficiency (about 96.5\%) in a short period of time (Abdurahman et al., 2011). It has been established that POME treatment with improved anaerobic treatment in a semi-commercial closed digester tank with sludge recycling achieved COD removal efficiency higher than 90\% (Busu et al., 2010).

Table 2, soil physicochemical properties before soil amendment shows that the parent soil was in the acidic region, with medium organic matter and low percentage base saturation. The low percentage base saturation (which is less than 35\%) suggests that it is an ultisoil (Orhue et al., 2005). Available phosphorus $(3.189 \mathrm{mg} / \mathrm{g})$ and nitrogen $(0.325 \mathrm{~g} / \mathrm{kg})$ indicate that the nutrient level of the soil is low and would not favour the growth of plant for high yield of crops. Soil textural analysis shows that the soil is sandy and therefore needs soil nutrient enhancement. 
Table 2. Soil Physicochemical Properties before Treatment

\begin{tabular}{ll}
\hline Parameters & Values \\
\hline $\mathrm{pH}$ & $5.140 \pm 0.010$ \\
Total Organic Carbon $(\mathrm{g} / \mathrm{Kg})$ & $6.410 \pm 0.010$ \\
Organic Matter $(\mathrm{g} / \mathrm{Kg})$ & $11.070 \pm 0.100$ \\
Nitrogen $(\mathrm{g} / \mathrm{Kg})$ & $0.325 \pm 0.010$ \\
Av. Phosphorus $(\mathrm{mg} / \mathrm{g})$ & $3.198 \pm 0.100$ \\
Potassium $(\mathrm{cmol} / \mathrm{Kg})$ & $0.145 \pm 0.200$ \\
Sodium $(\mathrm{cmol} / \mathrm{Kg})$ & $0.108 \pm 0.00$ \\
Magnesium $(\mathrm{cmol} / \mathrm{Kg})$ & $0.353 \pm 0.020$ \\
Calcium $(\mathrm{cmol} / \mathrm{Kg})$ & $0.423 \pm 0.001$ \\
Exchangeable Acidity $(\mathrm{cmol} / \mathrm{Kg})$ & $1.855 \pm 0.020$ \\
Cation Exchange Capacity $(\mathrm{cmol} / \mathrm{Kg})$ & $2.880 \pm 0.010$ \\
$\%$ Base Saturation & $31.940 \pm 0.020$ \\
Sand $(\%)$ & $87.147 \pm 0.110$ \\
Silt $(\%)$ & $6.540 \pm 0.120$ \\
Clay $(\%)$ & $6.316 \pm 0.001$ \\
\hline
\end{tabular}

Table 3 shows that application of the amendment enhanced the quality of the soils.

Table 3. Soil Physiochemical properties before and after treatment

\begin{tabular}{lllll}
\hline Sample & $0 \mathrm{ml}($ Control) & $200 \mathrm{ml}$ & $400 \mathrm{ml}$ & $600 \mathrm{ml}$ \\
\hline $\mathrm{pH}$ & $5.14 \pm 0.010^{\mathrm{a}}$ & $5.936 \pm 0.020^{\mathrm{c}}$ & $5.333 \pm 0.100^{\mathrm{b}}$ & $5.332 \pm 0.200^{\mathrm{b}}$ \\
T. Org. C g/Kg & $6.410 \pm 0.010^{\mathrm{a}}$ & $16.760 \pm 0.130^{\mathrm{b}}$ & $16.770 \pm 0.130^{\mathrm{b}}$ & $17.080 \pm 0.300^{\mathrm{c}}$ \\
Org. Mat. g/Kg & $11.070 \pm 0.100^{\mathrm{a}}$ & $28.920 \pm 0.020^{\mathrm{d}}$ & $28.870 \pm 0.300^{\mathrm{c}}$ & $27.470 \pm 0.201^{\mathrm{b}}$ \\
$\mathrm{Ca} \mathrm{cmol} / \mathrm{kg}$ & $0.423 \pm 0.001^{\mathrm{a}}$ & $0.613 \pm 0.003^{\mathrm{b}}$ & $0.620 \pm 0.020^{\mathrm{b}}$ & $0.620 \pm 0.100^{\mathrm{b}}$ \\
$\mathrm{Mg} \mathrm{cmol} / \mathrm{kg}$ & $0.353 \pm 0.0200^{\mathrm{d}}$ & $0.220 \pm 0.005^{\mathrm{b}}$ & $0.213 \pm 0.003^{\mathrm{a}}$ & $0.223 \pm 0.001^{\mathrm{c}}$ \\
$\mathrm{Av} . \mathrm{P} \mathrm{mg} / \mathrm{g}$ & $3.189 \pm 0.100^{\mathrm{a}}$ & $7.264 \pm 0.020^{\mathrm{c}}$ & $7.264 \pm 0.130^{\mathrm{c}}$ & $6.980 \pm 0.010^{\mathrm{b}}$ \\
$\mathrm{K} \mathrm{cmol} / \mathrm{kg}$ & $0.145 \pm 0.200^{\mathrm{a}}$ & $0.304 \pm 0.004^{\mathrm{c}}$ & $0.304 \pm 0.004^{\mathrm{c}}$ & $0.270 \pm 0.000^{\mathrm{b}}$ \\
$\mathrm{Na} \mathrm{cmol} / \mathrm{kg}$ & $0.108 \pm 0.001^{\mathrm{a}}$ & $0.153 \pm 0.001^{\mathrm{b}}$ & $0.153 \pm 0.009^{\mathrm{b}}$ & $0.147 \pm 0.010^{\mathrm{b}}$ \\
$\mathrm{N} \mathrm{g/Kg}$ & $0.325 \pm 0.010^{\mathrm{a}}$ & $0.8633 \pm 0.020^{\mathrm{b}}$ & $0.870 \pm 0.030^{\mathrm{b}}$ & $0.87 \pm 0.020^{\mathrm{b}}$ \\
$\mathrm{EA} \mathrm{cmol} / \mathrm{kg}$ & $1.856 \pm 0.020^{\mathrm{c}}$ & $1.328 \pm 0.110^{\mathrm{b}}$ & $1.328 \pm 0.015^{\mathrm{b}}$ & $1.148 \pm 0.178^{\mathrm{a}}$ \\
$\mathrm{CEC} \mathrm{cmol} / \mathrm{kg}$ & $2.880 \pm 0.010^{\mathrm{c}}$ & $2.620 \pm 0.100^{\mathrm{b}}$ & $2.620 \pm 0.020^{\mathrm{b}}$ & $2.410 \pm 0.200^{\mathrm{a}}$ \\
\% Base Sat. & $31.94 \pm 0.020^{\mathrm{a}}$ & $43.51 \pm 0.110^{\mathrm{b}}$ & $51.15 \pm 0.050^{\mathrm{d}}$ & $46.06 \pm 0.0300^{\mathrm{c}}$ \\
Sand $\%$ & $87.150 \pm 0.110^{\mathrm{d}}$ & $86.130 \pm 0.130^{\mathrm{c}}$ & $86.070 \pm 2.000^{\mathrm{b}}$ & $86.000 \pm 3.000^{\mathrm{a}}$ \\
Clay\% $\%$ & $6.320 \pm .001^{\mathrm{c}}$ & $5.570 \pm .020^{\mathrm{b}}$ & $5.530 \pm .030^{\mathrm{a}}$ & $5.507 \pm .006^{\mathrm{a}}$ \\
Silt\% & $6.540 \pm 0.120^{\mathrm{a}}$ & $8.30 \pm 0.100^{\mathrm{b}}$ & $8.400 \pm 0.200^{\mathrm{b}}$ & $8.330 \pm 0.110^{\mathrm{b}}$ \\
\hline
\end{tabular}

Results are expressed as mean of triplicate determinations. Superscripts represent statistical significance. Means with different alphabet remarks in the same row are significantly different at $5 \%$ probability level $(\mathrm{P}<0.05)$.

Values of soil organic carbon, N, P, K, Ca, Na and \% base saturation were significantly different $(\mathrm{P}<0.05)$, in no particular other but were higher than the control. Higher values in soil nutrient for the amended soil may be attributed to the application of the effluents. The result obtained agrees with (Orhue et al., 2005; Onyia et al., 2001; Nwoko and Ogunremi, 2010) with report on increase in soil nutrient on application of POME and RPE separately. The soil $\mathrm{pH}$ were also higher in the amended soil, however still remained in the acidic region for all the treatment which may be due to the acidic nature of the effluents. The CEC of the parent soil was higher 
than all the amended soils. The lower values of CEC of the amended soils suggest that nutrient bioavailability will be increased. The increase in soil nutrient also accounted for the reduction in the soil exchangeable acidity and CEC.

\section{Conclusion}

The anaerobic digestion was a successful biological treatment. Although in no consistent trend, there was evidence that the various treatments altered the soil properties better than the control. More trials in the greenhouse and field should be carried out to further affirm the bio-fertilizer potentials of the digestate.

\section{References}

Abdurahman, N.H., Rosli, Y.M., Azhari, N. H. and Tam, S. F. (2011). Biomethanation of Palm Oil Mill Effluent (POME) by Membrane Anaerobic System (MAS) using POME as a Substrate. World Academy of Science, Engineering and Technology, 51:419 - 424.

Ademoroti, C.M.A. (1996). Standard Method for Water and Effluent Analysis. Foludex Express Limited, Ibadan, $102-226$.

Ahmad, A., Ismail, S. and Bhatia. S. (2003). Water recycling from palm oil mill effluent (POME) using membrane technology. Desalination, 157: 87-95.

APHA. (1999). Standard Methods for Examination of Water and Wastewater/American Water Works Association/Water Environmental Federation. Washington DC.

Asia, I. O. and Akporhonor, E. E. (2007).Characterization and physicochemical treatment of Wastewater from Rubber processing factory. International Journal of Physical Science, 2 (3): 6167.

Babel S. and Rungruang, N. (2008). Treatment of natural rubber processing wastewater by combination of ozonation and activated sludge process. Proceedings: International Conference on Environmental Research and Technology (ICERT 2008), Agris.Fao.Org. Park royal Penang, Malaysia, 259- 263.

Busu, Z., Sulaiman, A., Hassan, M.A., Shirai, Y., Abd-Aziz, S., Yacob, S. and Wakisaka, M. (2010). Improved anaerobic treatment of palm oil mill effluent in a semi-commercial closed digester tank with sludge recycling and appropriate feeding strategy. Pertanika J. Trop. Agric. Sci., 33 (1): $27-37$.

Chua E.T. and Garces L.R. (1992). Waste Management in the Coastal Areas of the ASEAN Region: roles of governments, banking institutions, donor agencies, private sector and communities. The World Fish Centre, 117-126.

Hutagalung R. 1. (2003). Use of carbohydrate residues in Malaysia Department of Animal Sciences, University Pertanian Malaysia, Serdang, Selangor, Malaysia. http://archive.unu.edu/unupress/food/UNU06/cap_10.htm.

Leong S.T., Muttamara S. and Laortanakul P (2003). Reutilization of wastewater in a rubberbased processing factory: a case study in Southern Thailand. Resour. Conserv. Recycle, 37:159172.

Ma, A. N. (2000). Environmental Management for the Oil Palm Industry. Palm Oil Development, 30:1-10.

Mohammadi, M., Che Man, H., Hassan, M.A. and Lai Yee, Y. (2010).Treatment of wastewater from rubber industry in Malaysia. African Journal of Biotechnology, 9(38): 6233 - 6243. 
Nwoko, C.O. and Ogunremi, S. (2010). Evaluation of palm oil mill effluent on maize (Zea mays L) crop: Yield, tissue nutrient content and residual soil chemical properties. Australian Journal of crop Science, 4(1): $16-22$.

Ojuri, O. and Ola, S. A. (2010). Estimation of contaminant transport parameters for a tropical sand in a sand tank model. International Journal of Environmental Science and Technology (IJEST), 7(2): 385-394.

Ojuri, O.O., Ola, S.A., Fadugba, O.G. and Uduebor, M.A. (2014). Site remediation in Nigeria: proven and innovative technologies (recovery of free hydrocarbon from soil/groundwater). GEOMATE-Brisbane.

Onyia, C.O., Uyub, A. M., Akunna, J. C., Norulaini, N.A. and Omar, A.K.M. (2001). Increasing the fertilizer value of palm oil mill Sludge: Bioaugmentation in nitrification. Journal of Water Science and Technology, 44(10): 157-162.

Orhue, E. R. and Osaigbovo, A. U. (2013). The effect of rubber effluent on some chemical properties of soil and early growth of maize (Zea mays L.). Bayero Journal of Pure and Applied Sciences, 6(1): $164-168$.

Orhue, E. R. Osaigbovo, A. U. and Vwioko D. E. (2005). Growth of maize (Zea mays) and changes in some chemical properties of an ultisol amended with brewery effluent. African Journal of Biotechnology, 4(9): 973 - 978.

Osaigbovo, A. U. and Orhue, E. R. (2011). Effect of palm oil mill effluent on some soil chemical properties and growth of maize (Zea mays L). Nigerian Journal of Agriculture, Food and Environment, 7(3), 51-54.

Pal, U.R. (1991). Effect of Source and Rate of Nitrogen and Phosphorus on Yield, Nutrient Uptake and Apparent Fertilizer Nutrient Recoverery by Maize in Southern guinea Savannah. Journal of Agricultural science and Technology. 1 (1):21 - 24.

Rebecca, B. (Ed.) (2004). United States Department of Agriculture, Natural Resources Conservation Service, National Soil Centre (1996) soil survey and laboratory methods manual (Soil Survey Investigation Report No. 42, Version 3.0: 475-489).

Tekasakul P. and Tekasakul S. (2006). Environmental problems related to natural rubber production in Thailand. Aerosol. Res., 21: 122-129.

Sunarso, S., Johari, N.I., Widiasa, and Budiyono. (2012). The Effect of feed to inoculums ratio on rumen fluid as Inoculums. International Journal of waste resources. 2(1): 1-4

Udo, E. J., Ibia, T. O., Ogunwale, J. A., Anuo, A. O., \& Esu, I. E. (2009). Manual of soil, plant and water analysis. Sibon books Ltd.

Vavilin, V.A., Fernandez, B., Palatsi, J. and Flotats, X. (2008). Hydrolysis kinetics in anaerobic Degradation of particulate organic material: An overview. Journal of W aste Management, 28(6): $941-953$. 